\title{
EFFECT OF FREEZING DESICCATION ON COLD HARDINESS, ROS, MEMBRANE LIPID LEVELS AND ANTIOXIDANT STATUS IN SPRUCE SEEDLINGS
}

\author{
EMILIA KAMIŃSKA-RoŻEK, PAWEŁ M. PUKACKI \\ Physiology of Abiotic Stress Lab., Institute of Dendrology \\ Polish Academy of Sciences \\ Parkowa 5, 62-035 Kórnik, Poland \\ e-mail: ppukacki@man.poznan.pl \\ (Received: October 24, 2004. Accepted: February 10, 2005)
}

\begin{abstract}
The symptoms of oxidative stress and antioxidative response were investigated on Norway spruce seedlings subjected to freezing desiccation conditions. Three-year-old seedlings were exposed to freezing desiccation at $-3^{\circ} \mathrm{C}$ and $-10^{\circ} \mathrm{C}$ for 45 days in two acclimation stages: autumn (October) and winter (January). The stress enhanced the production of reactive oxygen species (ROS): superoxide radical anion $\left(\mathrm{O}_{2}{ }^{\circ}\right)$, and hydrogen peroxide $\left(\mathrm{H}_{2} \mathrm{O}_{2}\right)$. Concentrations of low molecular antioxidants: glutathione (GSH), ascorbic acid (AsA) and $\alpha$-tocopherol declined at both low temperatures and acclimation stages. The activity of superoxide dismutase (SOD) increased with ROS production, while guaiacol peroxidase (POX) activity decreased. The freeze-induced desiccation of needles was significantly correlated with the cold hardiness $\left(\mathrm{LT}_{50}\right)$, the level of low-molecular antioxidants, and POX activity, but not with SOD activity. Under extreme freezing desiccation conditions, these reactions continued, leading to the degradation of membrane phospholipids and a strong decrease in cold hardiness. The results show that membranes are the primary site of injury induced by ROS, produced under the influence of low temperature combined with dehydration. The acclimation response of Norway spruce needles to the oxidative stress generated by long-term cold and/or freezing desiccation is discussed.
\end{abstract}

KEY WORDS: antioxidants, cold hardiness, desiccation stress, oxidative stress, phospholipids, Picea.

\section{INTRODUCTION}

Winter desiccation is a common form of freezing injury in evergreen conifers during the autumn, winter and early spring in boreal regions. Frost drought injury occurs when the above ground or above-snowline parts of trees are exposed to wind, dry air and sun, while the ground and part of the stem remain frozen (Sutinen et al. 2001). In the needles of several conifer species during continued slow cooling, ice is formed in extracellular spaces, with concomitant cell volume reduction. This is an effect of migration of free cytoplasmic water from cells to extracellular ice, as a consequence of the low water vapour pressure in the apoplast. In woody plants, water migration out of cells is usually possible throughout winter, as all free cytoplasmic wa-

\footnotetext{
Abbreviations:

AsA - ascorbic acid; GSH - glutathione; $\mathrm{H}_{2} \mathrm{O}_{2}$ - hydrogen peroxide; $\mathrm{LT}_{50}$ - lethal temperature at which $50 \%$ of electrolytes are leached out of needles; MDA - malondialdehyde; $\mathrm{O}_{2}{ }^{--}$- superoxide radical anion; POX - guaiacol peroxidase; ROS - reactive oxygen species; SOD - superoxide dismutase
}

ter is frozen at $-60^{\circ} \mathrm{C}$ and lower temperatures (Zwiazek et al. 2001).

Strategies that allow conifers to survive freezing temperatures have been proposed on the basis of physiological and biochemical changes associated with freezing tolerance and freezing avoidance (Zwiazek et al. 2001; Arora et al. 2003). The cellular membranes are the primary site of freeze-induced dehydration injury (Yoshida 1979; Pukacki et al. 1991; Heino and Palva 2003). In addition, the plasma membrane prevents seeding of the intracellular solution by extracellular ice. Recent evidence indicates that at least some of the effects of freezing stress are mediated by reactive oxygen species (ROS) in plant systems (McKersie et al. 2000). It is now clear that ROS are involved in the molecular damage observed in plants exposed to an impressive variety of adverse conditions, including frost, drought, osmotic stress, and air pollution (Foyer and Noctor 2000; Pukacka and Pukacki 2000; Kacperska 2004). Plant antioxidant systems are thought to play a role in freeze detoxification mechanisms (McKersie et al. 2000). Central to the mechanisms are antioxidant metabolites, which include 
low-molecular antioxidants, such as ascorbic acid (AsA), glutathione (GSH), $\alpha$-tocopherol, and enzymatic antioxidants, such as SOD, catalase and POX. SOD activity is correlated with development of cold hardiness in autumn (Doulis et al. 1993; Polle et al. 1996). McKersie et al. (2000) showed that transgenic alfalfa, characterized by an increased expression of MnSOD, better regenerated frost injuries and showed a much higher winter survival rate. In Norway spruce, the maximum GSH content was recorded in December, while the lowest content was observed during the growth phase, from June to August (Polle et al. 1996; Doulis et al. 1993). On the other hand, ROS-induced peroxidation is considered to be an important mechanism of membrane degradation during long-term freezing desiccation of tissues, because polyunsaturated fatty acids are ideal targets for ROS attack (Kendall and McKersie 1989).

Glutathione may protect proteins from freezing-induced disulfide bound formation. The main, reducing effect of glutathione in the process of removal of $\mathrm{H}_{2} \mathrm{O}_{2}$ from chloroplasts, was presented by Foyer and Noctor (2000). AsA and GSH compounds play an important role as antioxidants in photosynthetic organs, because they react directly with ROS, recover $\alpha$-tocopherol, and are substrates for peroxidases in detoxification of $\mathrm{H}_{2} \mathrm{O}_{2}$ (Foyer and Noctor 2000).

The close relationship between ROS level and membrane degradation was noted by Kendall and McKersie (1989). Those authors reported that membrane injury results also in changed phase properties of lipid components of cell membranes, analysed by X-ray diffraction (Pukacki et al. 1991). On the other hand, it cannot be excluded that lipolytic enzymes associated with membranes (mainly phospholipase D) could also cause phospholipid degradation during the freezing desiccation stress. The activity of phospholipase $\mathrm{D}$ has been confirmed at temperatures below $0^{\circ} \mathrm{C}$ (Sikorska and Kacperska 1982).

In the present study we examined the mechanisms of tolerance to freezing desiccation stress of spruce seedlings under long-time moderate frost and low humidity level. We tested the hypothesis that prolonged freezing storage of spruce seedlings is associated with the strong desiccation, oxidative stress and can be related to cold hardiness. We examined the production of $\operatorname{ROS}\left(\mathrm{O}_{2}{ }^{--}, \mathrm{H}_{2} \mathrm{O}_{2}\right)$ in needles, changes in low molecular antioxidants and enzymatic scavenges SOD and POX activities in relation to freezing-induced desiccation and cold acclimation stage. In the available literature relatively little is known about the protective function of antioxidants in response to cold-storage conifer seedlings (as a source of oxidative stress).

\section{MATERIALS AND METHODS}

\section{Plant material and experimental treatments}

Three-year-old Norway spruce seedlings (Picea abies (L.) Karst.), provenance Węgierska Górka (49³4'N, $19^{\circ} 10^{\prime} \mathrm{E}$, altitude $750 \mathrm{~m}$ ), were used in this study. They were obtained from a forest nursery near Krotoszyn (Poland). In both experiments, started in autumn (October) and in winter (January), seedlings were stored for 15, 30 and 45 days in cold rooms at $-3^{\circ} \mathrm{C}$ at $64 \% \mathrm{RH}$ and at $-10^{\circ} \mathrm{C}$ at $55 \%$ $\mathrm{RH}$, under a 12-h day length in autumn and 8-h day length in winter at $95 \mu \mathrm{mol} \mathrm{m} \mathrm{m}^{-2} \mathrm{~s}^{-1}$ photosynthetically active radia- tion (PAR). The seedlings were covered with polyethylene foil (mild stress, MS) or uncovered (extreme stress, ES). The analyses were performed on 1-year-old needles. Control seedlings of the same provenance were kept outdoors, under the canopy of trees. They were weekly watered, and did not show any symptoms of desiccation stress. The air temperatures were monitored and data shown that their minimum never decreased below $-1^{\circ} \mathrm{C}$ in autumn and only three times to $-4^{\circ} \mathrm{C}$ in winter.

\section{Determination of cold hardiness}

This was performed according to Pukacki and Pukacka (1987). Needles of spruce were placed in test tubes in a computer-controlled freezer (Binder MK 53, Germany). After 0.5 -h equilibrium in $0^{\circ} \mathrm{C}$ the temperature was decreased by $3^{\circ} \mathrm{C} \mathrm{h}^{-1}$. Samples were withdrawn at $5^{\circ} \mathrm{C}$ intervals and allowed to thaw at $3^{\circ} \mathrm{C}$ overnight. After freezing and thawing, the tissues were put into deionized water $(0.1$ $\mathrm{g} \mathrm{ml}^{-1}$ ). The percentage of ion leakage from the samples, determined after $24 \mathrm{~h}$ incubation in room temperature and than by measuring its electrical conductivity. The conductivity was measured using a temperature-compensating conductivity meter (CPC-551, Elmetron, Poland). To measure the total conductivity, samples were killed by freezing at $-60^{\circ} \mathrm{C}$ for $80 \mathrm{~min}$, they were re-extracted for $24 \mathrm{~h}$ at room temperature in the original solution. The cold hardiness of needles was defined as the lethal temperature $\left(\mathrm{LT}_{50}\right)$ and was calculated to the temperature giving $50 \%$ ion leakage.

\section{Assessment of degradation of cell membranes}

Membrane degradation was assessed on the basis of: (1) electrolytic conductivity of the ions leaked from spruce needles into a solution according to Kamińska-Rożek and Pukacki (2004); the level of membrane degradation was expressed as percentage of the total electrolytes leaked, relative to those leaked from killed tissues; and (2) the level of membrane lipid peroxidation, measured as MDA content according to Heath and Packer (1968). The concentration of MDA was calculated from difference of the absorbance at $535 \mathrm{~nm}$ and $600 \mathrm{~nm}$ and excitation coefficient of $155 \mathrm{nM}^{-1} \mathrm{~cm}^{-1}$ (Heath and Packer 1968).

\section{ROS assays}

To assay superoxide anion radicals $\left(\mathrm{O}_{2}{ }^{--}\right), 0.2 \mathrm{~g}$ of spruce needles were soaked in $3 \mathrm{ml}$ of phosphate buffer at $\mathrm{pH} 7.8$ with $0.05 \% \mathrm{NBT}$ and $10 \mathrm{mM} \mathrm{NaN}_{3}$, and incubated at room temperature, according to Doke (1983). The total concentration of $\mathrm{O}_{2}{ }^{--}$was expressed as the ratio of absorption of the extract (read at $580 \mathrm{~nm}$ ) to dry weight of the needles.

To assay total $\mathrm{H}_{2} \mathrm{O}_{2}, 0.5 \mathrm{~g}$ of needles were ground in presence of liquid nitrogen. The powders obtained were homogenized with $5 \mathrm{ml}$ of $5 \%$ trichloroacetic acid (TCA) containing $10 \mathrm{mM}$ ethylenediaminetetraacetate (EDTA). The homogenate was filtered and then centrifuged at $12000 \mathrm{~g}$ for $15 \mathrm{~min}$. The total concentration of $\mathrm{H}_{2} \mathrm{O}_{2}$ was expressed as the ratio of measured absorption of the extract (read at $480 \mathrm{~nm}$ ) to dry weight of the needles according to Thurman et al. (1972).

\section{Separation and identification of phospholipids and $\alpha$-tocopherol}

Samples of $5 \mathrm{~g}$ of needles were ground in a mortar in 15 $\mathrm{ml}$ of a mixture of chloroform and methanol $(2: 1, \mathrm{v} / \mathrm{v})$. 
Phospholipids were separated according to Nichols et al. (1965) on TLC plates (Merck, No. 5721). Classes of phospholipid were identified and determined as inorganic $\mathrm{P}$ according to the method of Ames (1966). Quantities of the particular phospholipids were expressed as $\mu \mathrm{g} \mathrm{P} \mathrm{mg}{ }^{-1}$ of lipids. $\alpha$-Tocopherol, was assayed in the total lipid extract as previously described (Pukacki 2004). The analysis was conducted in a gas chromatograph Hewlett Packard 5890. The results were expressed per $\mathrm{g}$ of DW.

\section{Assays of low-molecular antioxidants}

For the assays of AsA and non-protein thiols, $0.5 \mathrm{~g}$ of needles were ground to a fine powder under liquid nitrogen and in $5 \mathrm{ml}$ of $5 \%$ trichloroacetic acid (TCA) and $10 \mathrm{mM}$ EDTA. The homogenate was filtered through two layers of cheesecloth, then centrifuged at $12000 \mathrm{~g}$ for $30 \mathrm{~min}$ at $4^{\circ} \mathrm{C}$, and the supernatant was used for the assays.

AsA content was assayed according to Law et al. (1983). The assay is based on the reduction of $\mathrm{Fe}^{3+}$ to $\mathrm{Fe}^{2+}$ by AsA in acidic solution. $\mathrm{Fe}^{2+}$ then forms complexes with bipirydyl, giving a pink colour with a maximum absorbance at $525 \mathrm{~nm}$. The concentration was determined by comparison with a standard curve.

Non-protein thiol content was determined according to Sedlak and Lindsay (1968), using Ellman's reagent [5,5'-dithiobis-(2-nitrobenzoic acid)] (DTNB). Absorbance was read at $412 \mathrm{~nm}$. The standard curve was made with glutathione. The applied method determines the total pool of
-SH groups. Research conducted by Doulis et al. (1993) shows that over $96 \%$ of -SH groups belong to the reduced form of glutathione (GSH). For this reason, the level of -SH groups determined by this method were described as the glutathione pool.

\section{Enzyme assays}

Needles ( $1 \mathrm{~g}$ ) were powdered in liquid nitrogen. The powder was transferred into a mortar containing $8 \mathrm{ml}$ of cold extraction buffer $\left(100 \mathrm{mM} \mathrm{KH} \mathrm{PO}_{4} / \mathrm{K}_{2} \mathrm{HPO}_{4} \mathrm{pH} 7.0,10\right.$ mM EDTA) and 1\% PVPP. Homogenates were centrifuged at $15000 \mathrm{~g}$ for $20 \mathrm{~min}$ at $4^{\circ} \mathrm{C}$. The supernatant was used for analysis as the crude enzyme: SOD and POX.

Total SOD activity (EC. 1.15.1.1.) was determined by measuring its ability to inhibit the photochemical reduction of NBT according to the method of Giannopolitis and Ries (1977). The reaction mixture contained $50 \mathrm{mM}$ phosphate buffer (pH 7.8), $1.3 \mathrm{mM}$ riboflavin, $0.1 \mathrm{mM}$ EDTA, $1 \mathrm{mM}$ dithioeritritol, $63 \mathrm{mM} \mathrm{NBT}$, and $50 \mu \mathrm{l}$ of enzyme extract. Tubes were placed under fluorescent lamp and absorbance was recorded at $560 \mathrm{~nm}$. A nonirradiated reaction mixture served as the control. One unit of SOD activity was defined as the amount of enzyme required to cause $50 \%$ inhibition of the rate of NBT reduction. SOD activity was expressed as $\mathrm{U} \mathrm{g}^{-1} \mathrm{DW}$ of needles as previously described (Pukacka and Pukacki 2000).

POX (EC.1.11.1.7.) activity was measured in the reaction of oxidation of guaiacol at $470 \mathrm{~nm}\left(\mathrm{e}=26.6 \mathrm{mM}^{-1} \mathrm{~cm}^{-}\right.$
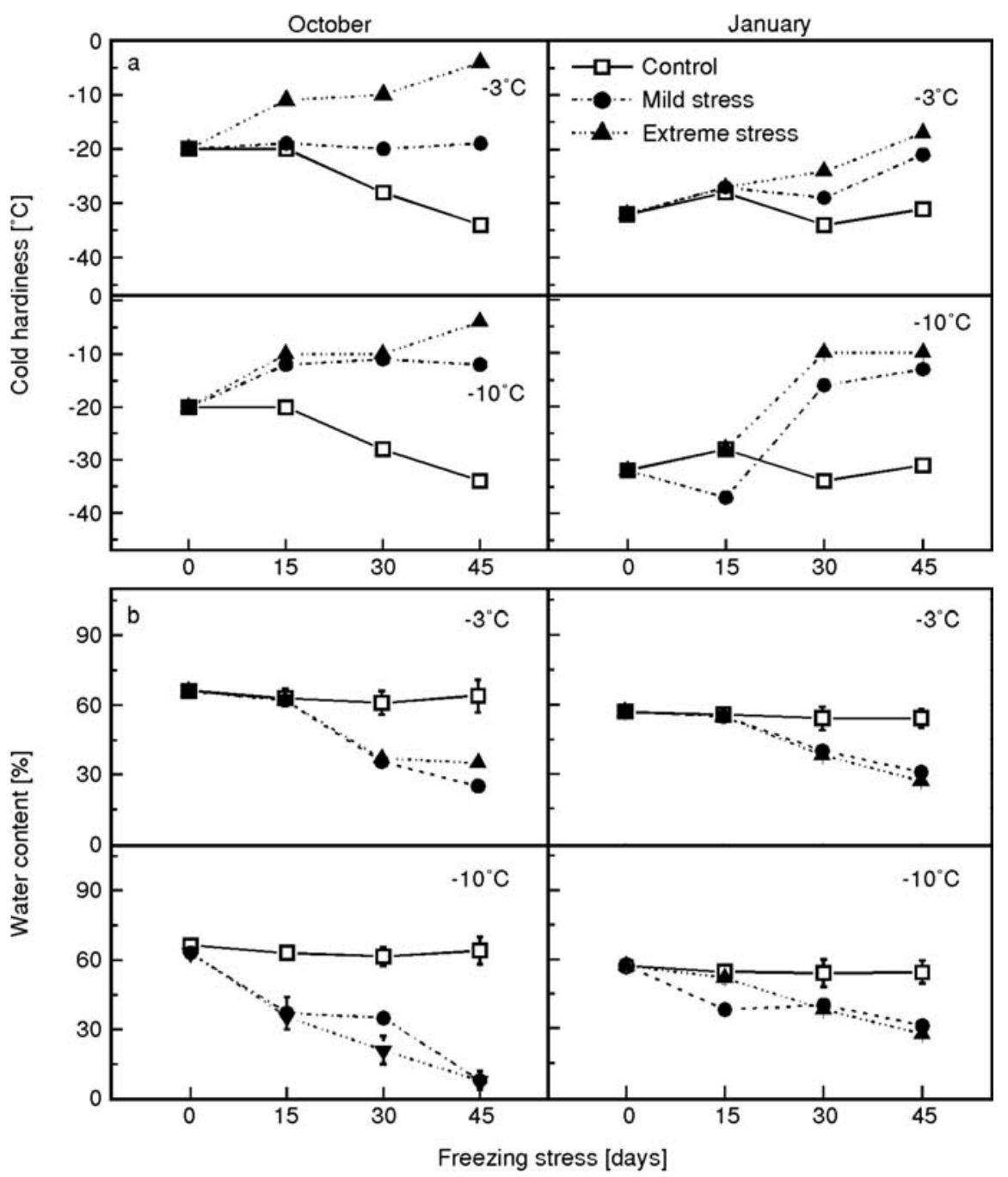

Fig. 1. Effects of long-term freezing desiccation on (a) cold hardiness $\left(\mathrm{LT}_{50}\right)$ and (b) water content of needles in Norway spruce seedlings subjected to various treatments: two temperatures $\left(-3^{\circ} \mathrm{C},-10^{\circ} \mathrm{C}\right)$ and three levels of freezing desiccation: mild stress (MS), extreme stress (ES) and control, in two acclimation stages: in October and January. Time zero, before moving the seedlings into the cold rooms. Data significantly different from control: $* P<0.05$. Mean \pm SD $(\mathrm{n}=6)$. 


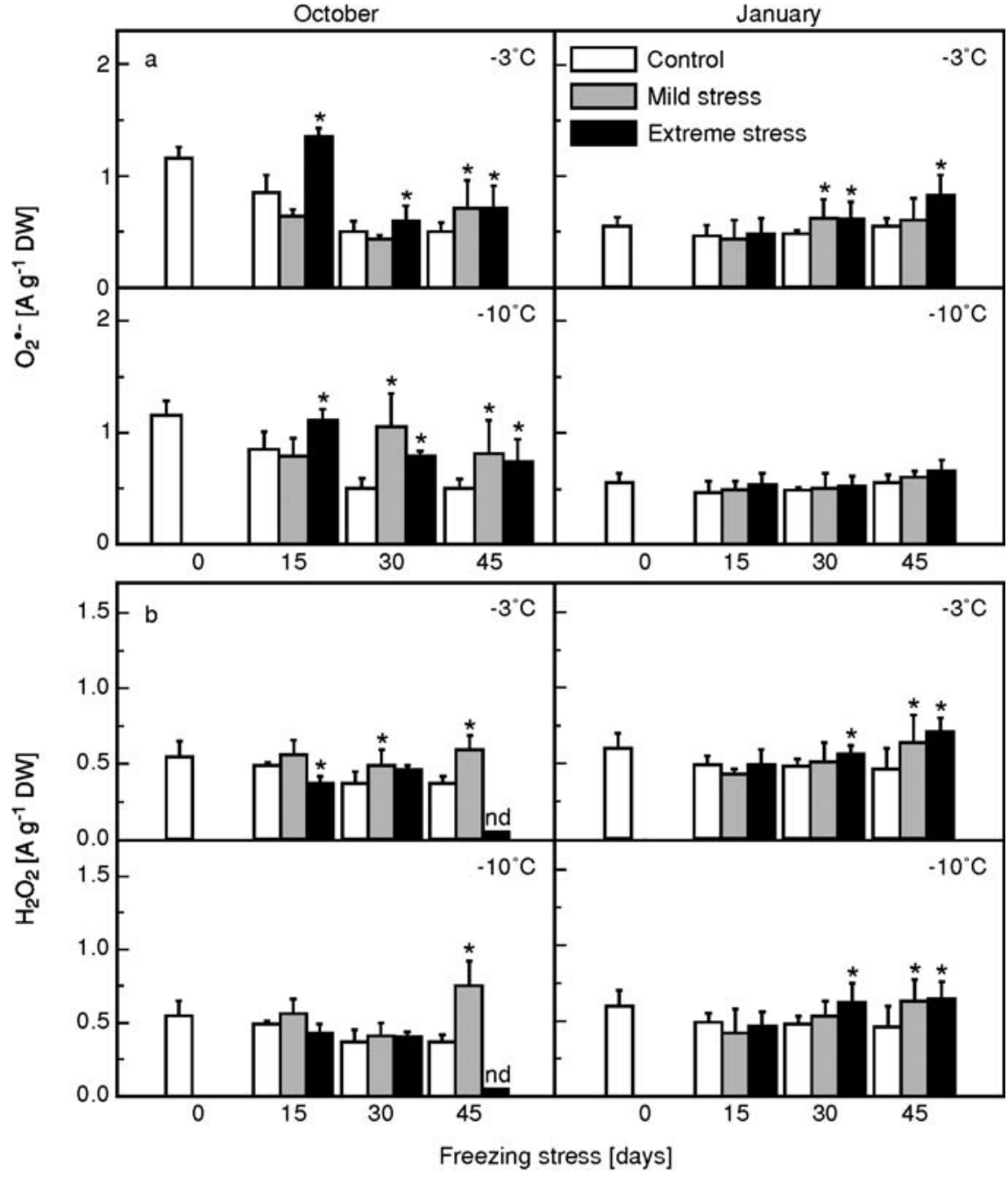

Fig. 2. Effects of long-term freezing desiccation on (a) superoxide anion radical $\left(\mathrm{O}_{2}{ }^{-}\right)$ and (b) hydrogen peroxide $\left(\mathrm{H}_{2} \mathrm{O}_{2}\right)$ content of needles in Norway spruce seedlings subjected to various treatments: two temperatures $\left(-3^{\circ} \mathrm{C},-10^{\circ} \mathrm{C}\right)$ and three levels of freezing desiccation: mild stress (MS), extreme stress (ES) and control, in October and January. Otherwise as in Figure 1.
1) according to Chance and Maehly (1955). The reaction mixture contained of $100 \mathrm{mM}$ phosphate buffer $\mathrm{pH} 7.0,1 \%$ guaiacol, $0.2 \mathrm{M} \mathrm{H}_{2} \mathrm{O}_{2}$, and 50-100 $\mu 1$ of enzyme extract; the activity was expressed as $\mu \mathrm{kat}^{\mathrm{mg}^{-1}}$ protein.

The protein content of crude enzyme extract was estimated according to Bradford (1976) by using bovine serum albumin (BSA) as a standard. All the spectrophotometric measurements were made with a UV-VIS 2401, PC spectrophotometer (Shimadzu Scientific Instruments, Columbia, MD).

\section{Statistical analysis}

Data are presented as means \pm standard deviation (SD), with $\mathrm{n}=6$. The significance of differences between the control and stressed plants were assessed on the basis of analysis of one-way variance (ANOVA) and linear regression for each parameter. Significant differences between means were determined by Duncan's multiple range test and significance levels are indicated as $P<0.05$.

\section{RESULTS}

\section{Cold hardiness and water relations}

Plants under freezing desiccation at extreme stress (ES) after 15 days in autumn had a lower water content of needles than in the control, it was $41 \%$ at $-10^{\circ} \mathrm{C}$, but in winter
$52 \%$. In MS plants at $-10^{\circ} \mathrm{C}$ after 30 days of desiccation in both acclimation stages (autumn and winter) it decreased by $21 \%$ and $38 \%$ respectively (Fig. 1). As a result of freezing desiccation, cold hardiness $\left(\mathrm{LT}_{50}\right)$ of ES needles at $-3^{\circ} \mathrm{C}$ decreased from $-20^{\circ} \mathrm{C}$ to $-4^{\circ} \mathrm{C}$ after 45 days (Fig. 1). However, in winter at $-3^{\circ} \mathrm{C}$ in $\mathrm{ES}$ plants after 45 days of freezing desiccation, the cold hardiness of needles decreased from $-32^{\circ} \mathrm{C}$ to $-17^{\circ} \mathrm{C}$ (Fig. 1). The water content of needles was significantly negatively correlated with cold hardiness $\left(\mathrm{LT}_{50}\right)$ at $-3^{\circ} \mathrm{C}$ for ES plants, both in autumn $\left(\mathrm{r}^{2}=\right.$ $0.91, P=0.001)$ and in winter $\left(\mathrm{r}^{2}=0.69, P=0.01\right)$. After 30 and 45 days of storage, seedlings at $-10^{\circ} \mathrm{C}$ in winter had a significantly lower cold tolerance than those stored at $3^{\circ} \mathrm{C}$ (Fig. 1). The highest rate of water loss was observed from ES needles in autumn at $-10^{\circ} \mathrm{C}$, while in winter was about $50 \%$ lower.

\section{$\mathrm{O}_{2}{ }^{--}, \mathrm{H}_{2} \mathrm{O}_{2}$ levels and lipid peroxidation}

The freezing desiccation increased $\mathrm{H}_{2} \mathrm{O}_{2}$ and $\mathrm{O}_{2}{ }^{--}$levels in needles, in both autumn and winter, in relation to the controls (Fig. 2). In autumn the $\mathrm{O}_{2}{ }^{--}$content in ES plants at both temperatures $\left(-3^{\circ} \mathrm{C}\right.$ and $\left.-10^{\circ} \mathrm{C}\right)$ increased after 15 days by $57 \%$ and $29 \%$, respectively, as compared to the control (Fig. 2a). By contrast, in winter at ES plants, $\mathrm{O}_{2}{ }^{--}$content was increased by $26 \%$ at $-3^{\circ} \mathrm{C}$ after 30 days of stress. In winter at $-3^{\circ} \mathrm{C}$, effect of freezing desiccation treatment on $\mathrm{O}_{2}{ }^{-}$was significantly correlated with water content of 

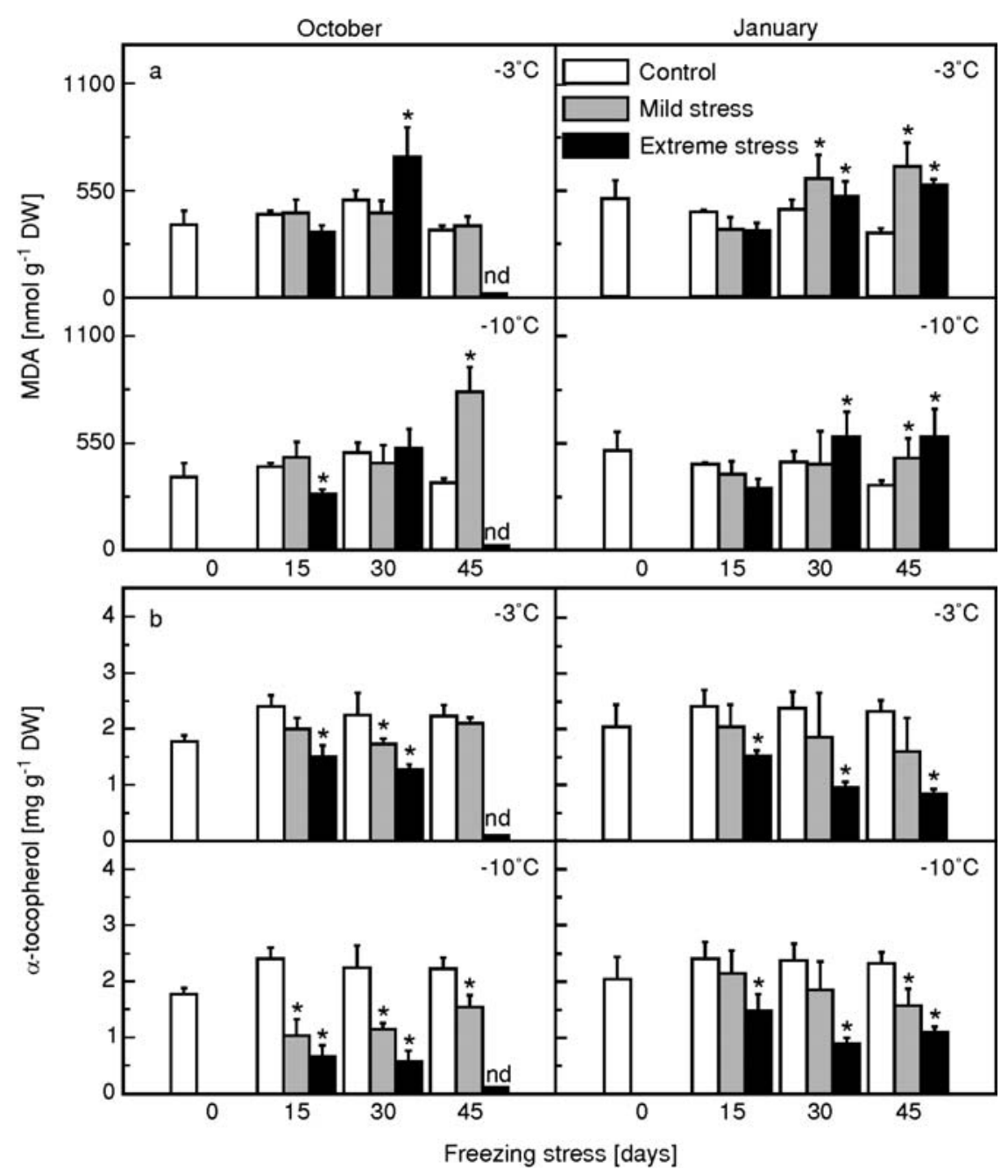

Fig. 3. Effects of long-term freezing desiccation on (a) malondialdehyde (MDA) and (b) $\alpha$-tocopherol content of needles in Norway spruce seedlings subjected to various treatments: two temperatures $\left(-3^{\circ} \mathrm{C},-10^{\circ} \mathrm{C}\right)$ and three levels of freezing desiccation: MS, ES, and control, in October and January. Otherwise as for Figure 1.

spruce needles $\left(\mathrm{r}^{2}=0.53, P=0.01\right)$. The freezing desiccation also caused an increase in $\mathrm{H}_{2} \mathrm{O}_{2}$ level in spruce needles (Fig. 2b). In autumn at $-3^{\circ} \mathrm{C}$, the level of $\mathrm{H}_{2} \mathrm{O}_{2}$ already in mildly stressed (MS) plants, increased by about $16 \%$, whereas in ES plants it increased, by $22 \%$ after 30 days. In winter, an increase was observed after 30 days of the stress and was the highest for $\mathrm{H}_{2} \mathrm{O}_{2}$ in ES plants at both temperatures (Fig. 2b). The increase in $\mathrm{H}_{2} \mathrm{O}_{2}$ in ES plants amounted to $16 \%$ at $-3^{\circ} \mathrm{C}$ and $30 \%$ at $-10^{\circ} \mathrm{C}$, while in MS plants no significant differences were observed. However, the changes at $-10^{\circ} \mathrm{C}$ in winter for $\mathrm{O}_{2}{ }^{--}$level and in autumn for $\mathrm{H}_{2} \mathrm{O}_{2}$ level were not significant (Fig. 2).

Freezing desiccation of seedlings caused membrane lipid degradation after 30 days, reflected in a higher permeability, as increased ion leakage from needle cells in comparison with the control, in both autumn and winter (Fig. 3 and Table 1). The greatest ion leakage was detected in ES seedlings after 15 days of stress both in autumn (when it reached 58\%), and in winter after 30 days (when it reached $59 \%$ ) (Table 1). However, ion leakage percentage in winter at $-10^{\circ} \mathrm{C}$ after 30 days showed the same pattern below $50 \%$ in both freezing desiccation leaves (MS and ES). No significant differences were observed in winter after 45 days, between the treated seedlings kept at $-3^{\circ} \mathrm{C}$ and $-10^{\circ} \mathrm{C}(\mathrm{Ta}-$ ble 1). The content of malondialdehyde (MDA) was used as an indicator of fatty acids peroxidation (Fig. 3a). In autumn, an increase in MDA level was observed after 30 days of freezing desiccation of ES plants at $-3^{\circ} \mathrm{C}$, but at $-10^{\circ} \mathrm{C}$ no significant changes were detected (Fig. 3a). By contrast, in winter, MDA content of ES plants increased by $16 \%$ at $-3{ }^{\circ} \mathrm{C}$ and by $29 \%$ at $-10^{\circ} \mathrm{C}$. In autumn, a reaction was observed in $\mathrm{MS}$ plants already after 15 days at $-10^{\circ} \mathrm{C}$, as MDA increased by $12 \%$. In winter the first reaction of MS plants was recorded after 30 days at $-3^{\circ} \mathrm{C}$, when the MDA level increased by $30 \%$, and after 45 days at $-10^{\circ} \mathrm{C}$, when it increased by $42 \%$ (Fig. 3a).

In autumn the phosphatidylcholine to phosphatidic acid (PC/PA) ratio was lower than in the control already after 15 days of stress: at $-10^{\circ} \mathrm{C}$ it declined to $69 \%$ in MS seedlings and to $26 \%$ in ES plants, of the control level (Table 1). In ES plants after 30 days of stress the PC/PA ratio at $-3^{\circ} \mathrm{C}$ declined to about $56 \%$ of the control level. An exceptional situation was observed in winter, when the PC/PA ratio after 45 days at $-10^{\circ} \mathrm{C}$ decreased to $79 \%$ in $\mathrm{MS}$ plants and to $63 \%$ in ES plants. The PC/PA ratio in autumn at $-10^{\circ} \mathrm{C}$ declined significantly to $44 \%$ in MS seedlings of the control level (Table 1).

\section{Antioxidants}

Freezing desiccation decreased concentrations of lowmolecular antioxidants: $\alpha$-tocopherol, GSH and AsA in the needles (Figs 3b, 4). The level of $\alpha$-tocopherol declined in autumn after 30 days at $-3^{\circ} \mathrm{C}$ to $67 \%$ in MS plants and to $56 \%$ in ES plants, while at $-10^{\circ} \mathrm{C}$ to $51 \%$ and $25 \%$, respec- 

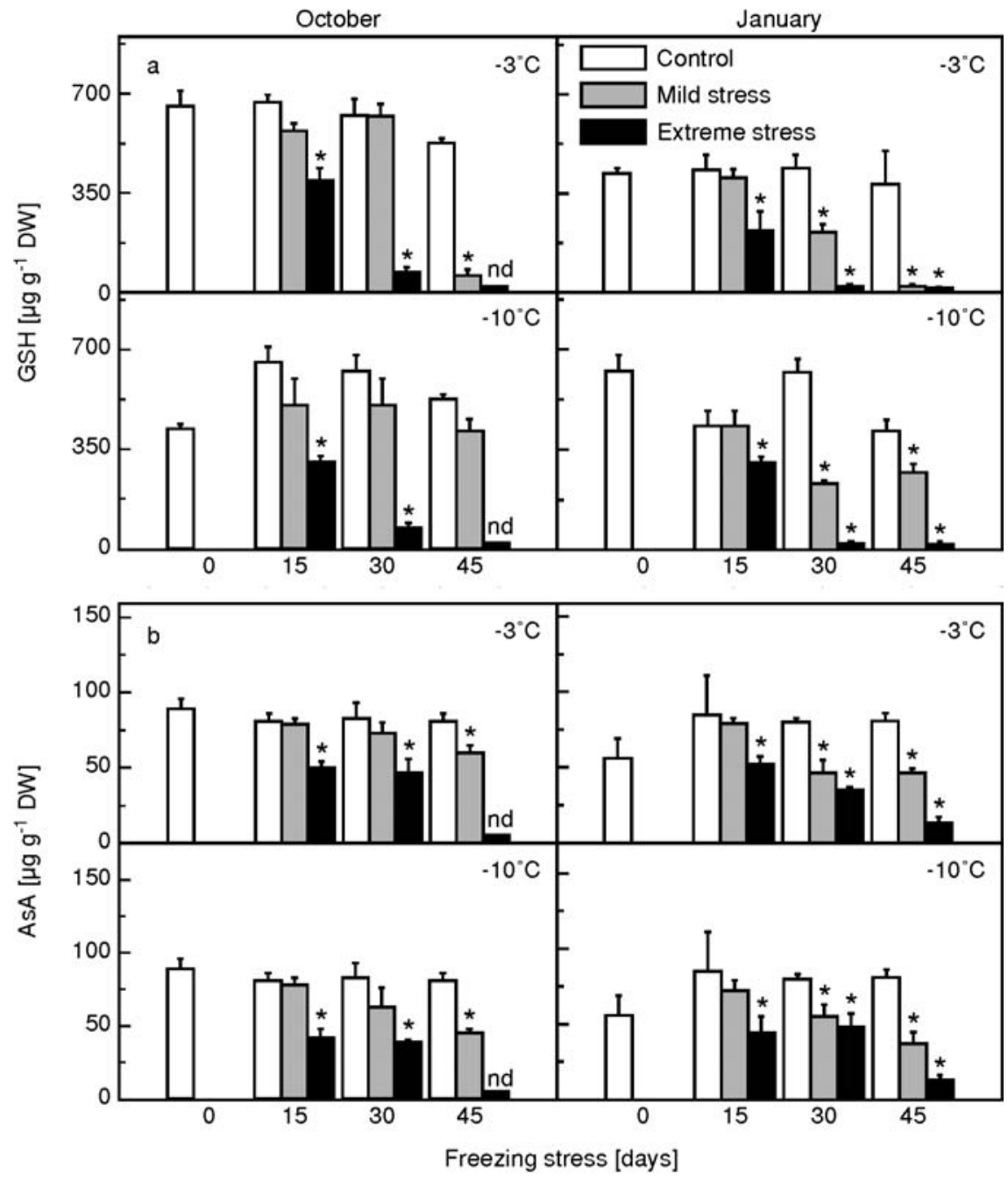

Fig. 4. Effects of long-term freezing desiccation on (a) glutathione (GSH) and (b) ascorbic acid (AsA) content of needles in Norway spruce seedlings subjected to various treatments: two temperatures $\left(-3^{\circ} \mathrm{C},-10^{\circ} \mathrm{C}\right)$ and three levels of freezing desiccation: MS, ES and control, in October and January. Otherwise as in Figure 1.

TABLE 1. Ion leakage and phosphatidylcholine (PC) to phosphatidic acid (PA) ratio in needles of Norway spruce seedlings exposed for 15,30 and 45 days to mild (MS) or extreme (ES) freeze-induced desiccation at $-3^{\circ} \mathrm{C}$ and $-10^{\circ} \mathrm{C}$, in October and January. Data significantly different from control: $* P<0.05, * * P<0.01$. Mean $\pm \mathrm{SD}(\mathrm{n}=6)$; nd - not determined.

aTime zero, before moving the seedlings into the cold rooms.

\begin{tabular}{|c|c|c|c|c|c|}
\hline \multirow{2}{*}{$\begin{array}{l}\text { Stress duration } \\
\text { (days) }\end{array}$} & \multirow{2}{*}{ Treatment } & \multicolumn{2}{|c|}{ Ion leakage $(\%)$} & \multicolumn{2}{|c|}{ PC/PA $(\mu \mathrm{g} / \mu \mathrm{g})$} \\
\hline & & October & January & October & January \\
\hline $0^{\mathrm{a}}$ & Start of stress & $13.7 \pm 3.3$ & $20.0 \pm 2.1$ & $4.3 \pm 1.2$ & $4.6 \pm 2.2$ \\
\hline \multirow[t]{2}{*}{15} & $\begin{array}{l}\text { Control } \\
-3^{\circ} \mathrm{C} \text { MS } \\
\mathrm{ES}\end{array}$ & $\begin{array}{l}13.8 \pm 4.1 \\
18.9 \pm 1.9 \\
57.7 \pm 5.6\end{array}$ & $\begin{array}{l}20.2 \pm 4.0 \\
31.1 \pm 7.9 \\
29.9 \pm 7.3\end{array}$ & $\begin{array}{r}4.6 \pm 1.3 \\
13.5 \pm 1.0 \\
4.7 \pm 1.1\end{array}$ & $\begin{array}{l}4.6 \pm 1.3 \\
6.5 \pm 2.0 \\
6.3 \pm 1.0\end{array}$ \\
\hline & $\begin{array}{l}-10^{\circ} \mathrm{C} \mathrm{MS} \\
\mathrm{ES}\end{array}$ & $\begin{array}{l}39.4 \pm 6.2 \\
52.3 \pm 5.3\end{array}$ & $\begin{array}{l}15.5 \pm 5.5 \\
37.6 \pm 6.4\end{array}$ & $\begin{array}{l}3.2 \pm 0.8^{*} \\
1.2 \pm 0.7^{*}\end{array}$ & $\begin{array}{l}2.8 \pm 1.2^{*} \\
3.4 \pm 1.3^{*}\end{array}$ \\
\hline \multirow[t]{2}{*}{30} & $\begin{array}{l}\text { Control } \\
-3^{\circ} \mathrm{C} \text { MS } \\
\text { ES }\end{array}$ & $\begin{array}{r}7.2 \pm 1.4 \\
29.5 \pm 9.0 \\
53.0 \pm 3.1\end{array}$ & $\begin{array}{l}18.7 \pm 1.8 \\
66.7 \pm 3.0 \\
58.5 \pm 2.3\end{array}$ & $\begin{array}{l}3.4 \pm 0.8 \\
4.9 \pm 1.2 \\
1.9 \pm 1.0\end{array}$ & $\begin{array}{l}6.3 \pm 1.8 \\
3.0 \pm 2.2^{*} \\
2.2 \pm 2.1^{*}\end{array}$ \\
\hline & $\begin{array}{l}-10^{\circ} \mathrm{C} \mathrm{MS} \\
\mathrm{ES}\end{array}$ & $\begin{array}{l}43.7 \pm 5.2 \\
54.3 \pm 5.6\end{array}$ & $\begin{array}{l}38.1 \pm 5.2 \\
43.4 \pm 7.0\end{array}$ & $\begin{array}{l}1.9 \pm 0.2 * \\
1.2 \pm 1.1 * *\end{array}$ & $\begin{array}{l}5.6 \pm 0.7 \\
2.5 \pm 1.4^{*}\end{array}$ \\
\hline \multirow[t]{2}{*}{45} & $\begin{array}{l}\text { Control } \\
-3^{\circ} \mathrm{C} \text { MS } \\
\mathrm{ES}\end{array}$ & $\begin{array}{c}7.3 \pm 2.8 \\
30.9 \pm 5.8 \\
\text { nd }\end{array}$ & $\begin{array}{l}16.0 \pm 2.3 \\
58.8 \pm 3.1 \\
61.0 \pm 1.8\end{array}$ & $\begin{array}{l}4.9 \pm 0.6 \\
5.0 \pm 0.7 * * \\
\text { nd }\end{array}$ & $\begin{array}{l}3.8 \pm 0.8 \\
4.0 \pm 1.3 \\
1.7 \pm 0.4^{*}\end{array}$ \\
\hline & $\begin{array}{l}-10^{\circ} \mathrm{C} \mathrm{MS} \\
\mathrm{ES}\end{array}$ & $\begin{array}{c}55.5 \pm 7.1 \\
\text { nd }\end{array}$ & $\begin{array}{l}61.2 \pm 6.1 \\
66.5 \pm 5.0\end{array}$ & $\begin{array}{l}2.2 \pm 0.2 * * \\
\text { nd }\end{array}$ & $\begin{array}{l}3.0 \pm 0.6^{*} \\
2.4 \pm 1.2^{* * *}\end{array}$ \\
\hline
\end{tabular}


tively, of the control level (Fig. 3b). In winter the respective values were: $88 \%$ and $40 \%$ of the control level at $-3{ }^{\circ} \mathrm{C}$, and $88 \%$ and $38 \%$ at $-10^{\circ} \mathrm{C}$. Thus in both experiments greater changes were recorded at $-10^{\circ} \mathrm{C}$ than at $-3^{\circ} \mathrm{C}$ (Fig. $3 \mathrm{~b}$ ).

After 30 days at $-3^{\circ} \mathrm{C}$, GSH level in ES plants declined significantly, to $11 \%$ of the control level. At the same time at $-10^{\circ} \mathrm{C}$, the levels were decreased to $81 \%$ of the control level in MS plants and to only $6 \%$ in ES plants. In winter the observed changes were even greater (Fig. 4). In the case of glutathione, the greatest changes were recorded in the needles of ES plants in autumn at both temperatures $\left(-3^{\circ} \mathrm{C}\right.$ and $\left.-10^{\circ} \mathrm{C}\right)$ (Fig. $\left.4 \mathrm{a}\right)$. After 30 days at $-3^{\circ} \mathrm{C}$, the amount of GSH declined significantly, to $49 \%$ of the control level in MS plants and to $5 \%$ in ES plants, while at $-10^{\circ} \mathrm{C}$ to $73 \%$ and $8 \%$, respectively. In autumn the GSH concentration in spruce seedlings at $-3^{\circ} \mathrm{C}$ was significantly correlated, $\mathrm{r}^{2}=0.81(P=0.01)$ with cold hardiness (Table 2$)$.

AsA content also declined during freezing desiccation (Fig. 4b). The decline was greater in ES plants at both temperatures. In autumn, after 30 days at $-3^{\circ} \mathrm{C}$, AsA levels decreased to $87 \%$ in MS plants and $56 \%$ in ES plants, as compared to the control level, while at $-10^{\circ} \mathrm{C}$ the respective values were: $75 \%$ and $46 \%$. MS needles in autumn showed a higher AsA content of needles after 30 days of stress than in winter. In winter, after 30 days at $-3^{\circ} \mathrm{C}$, AsA decreased to $58 \%$ in MS plants and to $44 \%$ in ES plants, while at $-10^{\circ} \mathrm{C}$ to $68 \%$ and $60 \%$, respectively, of the control level. AsA concentration was significantly positively correlated
TABLE 2. The correlation $\left(\mathrm{r}^{2}\right)$ values for the linear regression of $\alpha$-tocopherol, glutathione (GSH) and ascorbic acid (AsA) concentrations as well as superoxide dismutase (SOD) and guaiacol peroxidase (POX) activities against of cold hardiness $\left(\mathrm{LT}_{50}\right)$ for spruce needles exposed to freezing desiccation stress at $-3^{\circ} \mathrm{C}$ and $-10^{\circ} \mathrm{C}$, in October and January.

\begin{tabular}{lllll}
\hline \multirow{2}{*}{ Antioxidants } & \multicolumn{2}{c}{ October } & \multicolumn{2}{c}{ January } \\
\cline { 2 - 5 } & $-3^{\circ} \mathrm{C}$ & $-10^{\circ} \mathrm{C}$ & $-3^{\circ} \mathrm{C}$ & $-10^{\circ} \mathrm{C}$ \\
\hline$\alpha$-tocopherol & $0.70^{*}$ & $0.72^{*}$ & $0.61^{*}$ & $0.62 *$ \\
GSH & $0.81^{* *}$ & 0.44 & $0.63^{*}$ & $0.57^{*}$ \\
AsA & $0.71^{*}$ & 0.54 & $0.52^{*}$ & 0.51 \\
SOD & 0.29 & 0.04 & 0.09 & 0.45 \\
POX & 0.29 & $0.78^{*}$ & 0.30 & 0.35 \\
\hline
\end{tabular}

Significance levels: $* P<0.05, * * P<0.01$.

with cold hardiness of needles at $-3^{\circ} \mathrm{C}$ in autumn and winter $\left(\mathrm{r}^{2}=0.71\right.$ and $\mathrm{r}^{2}=0.52$, respectively, $\left.P=0.05\right)$ (Table 2$)$. $\alpha$-Tocopherol concentration had the next strongest correlation in autumn and winter with cold hardiness $\left(\mathrm{LT}_{50}\right)$ of needles $\left(r^{2}=0.61\right.$ to $\left.r^{2}=0.72\right)($ Table 2$)$.

SOD activity in autumn greatly increased in stressed plants as compared to the control (Fig. 5a): in ES plants at $-10^{\circ} \mathrm{C}$ by $138 \%$ already after 15 days, while in MS plants at $-3^{\circ} \mathrm{C}$ by $131 \%$ after 30 days. In winter, SOD activity markedly increased at $-10^{\circ} \mathrm{C}$ as late as after 45 days: by $33 \%$ in ES plants and by $27 \%$ in MS plants. Thus the increase in SOD activity under the influence of freezing desiccation was lower in winter than in autumn, although the SOD le-
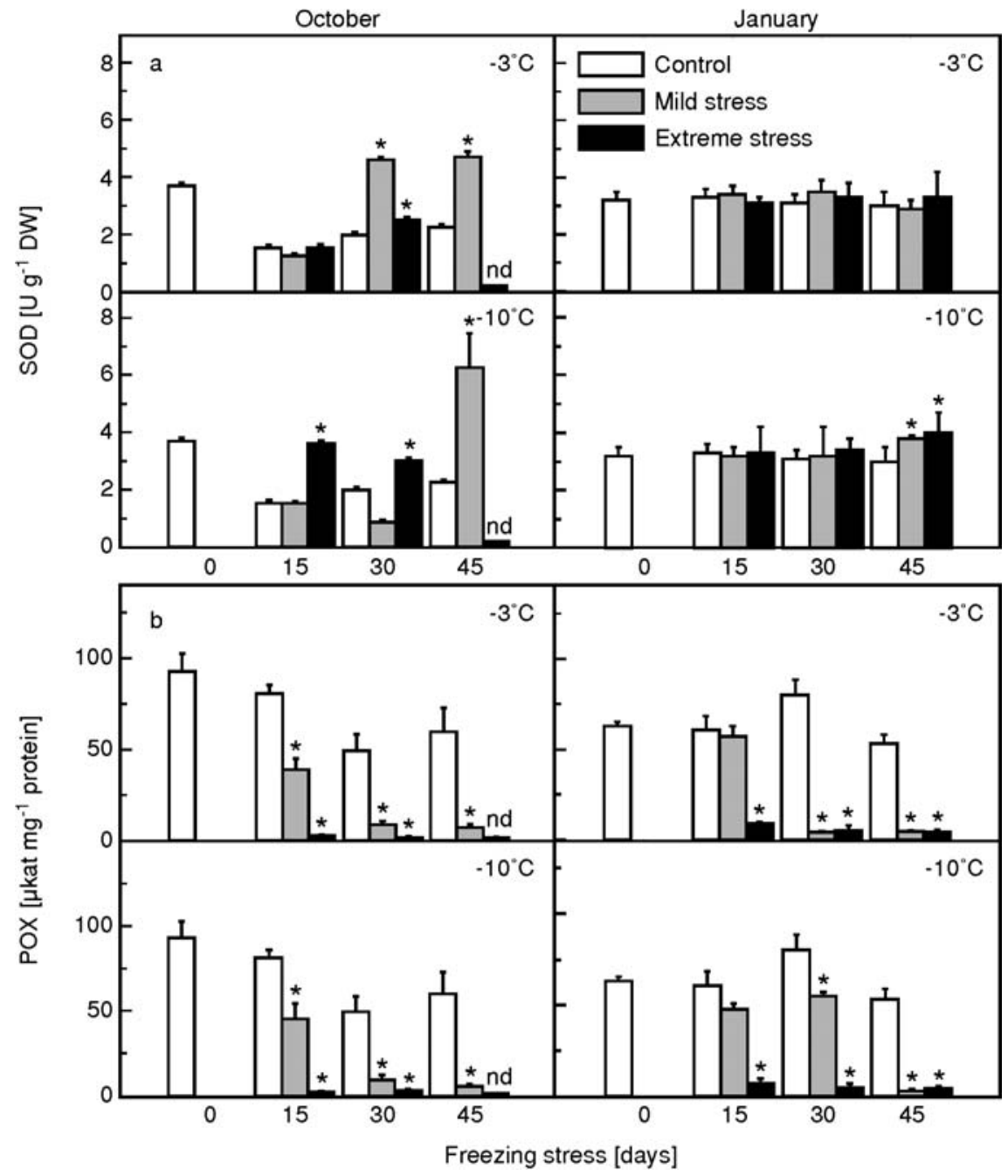

Fig. 5. Effects of long-term freezing desiccation on (a) superoxide dismutase (SOD) and (b) guaiacol peroxidase (POX) activity of needles in Norway spruce seedlings subjected to various treatments: two temperatures $\left(-3^{\circ} \mathrm{C},-10^{\circ} \mathrm{C}\right)$ and three levels of freezing desiccation: MS, ES and control, in October and January. Otherwise as in Figure 1. 
vels in control and stressed plants were higher in winter than in autumn. POX activity in autumn rapidly declined in ES plants already after 15 days: to $2 \%$ at both temperatures, as compared to the control level (Fig. 5b). Also in MS plants it markedly decreased after 15 days of stress: to $50 \%$ of the control level. In winter, POX activity in ES plants declined significantly, to $14 \%$ of the control level after 15 days at both temperatures, while in MS plants it declined after 30 days: to $5 \%$ of the control level at $-3{ }^{\circ} \mathrm{C}$ and to $69 \%$ at $-10^{\circ} \mathrm{C}$ (Fig. 5b). POX was positively correlated with water content at $-3^{\circ} \mathrm{C}$ in autumn and in winter $\left(r^{2}=0.50\right.$ and $\mathrm{r}^{2}=0.77, P=0.01$, respectively), and at $-10^{\circ} \mathrm{C}$ in autumn with cold hardiness $\left(\mathrm{r}^{2}=0.78, P=0.05\right)$, (Table 2$)$.

\section{DISCUSSION}

The water status of plant tissues is associated with acclimation stages and low-temperature stress tolerance (Arora et al. 2003). Results of this study show that the injury and cold hardiness of spruce needles to long-term freezing desiccation depends on the loss of water, and occurrence of oxidative stress. Freezing desiccation exerts a stronger effect on ROS production in needles at an early phase of cold acclimation in autumn (October) than in the fully cold-acclimated seedlings in winter (January). An increase in production of $\operatorname{ROS}\left(\mathrm{O}_{2}{ }^{--}\right.$and $\left.\mathrm{H}_{2} \mathrm{O}_{2}\right)$ was observed at both levels of desiccation (MS and $\mathrm{ES}$ ) and at both low temperatures (Fig. 2). In response to any stress, the flux of $\mathrm{H}_{2} \mathrm{O}_{2}$ generation is increased. Similarly, $\mathrm{H}_{2} \mathrm{O}_{2}$ induces synthesis of heat shock proteins and tolerance to low temperatures (Pastori and Foyer 2002). This suggests that at studied temperatures, oxidative stress was induced. Similar observations were made by McKersie et al. (2000) in herbaceous plants.

Both the results presented above and published data attest to associations between cell desiccation, oxidative stress, and freezing injuries. Results of this study indicate that the first symptoms of damage can be observed in cell membranes. A similar effect of drought stress on solute leakage has been observed in spruce seedlings subjected to freeze-induced desiccation and in those subjected to soil drought (Kamińska-Rożek and Pukacki 2004). Results of the present study show that ROS generation and degradation of membrane phospholipids depend more strongly on the level of freezing desiccation (MS versus ES) than on the applied temperature $\left(-3^{\circ} \mathrm{C}\right.$ versus $\left.-10^{\circ} \mathrm{C}\right)$ (Table 1$)$.

In this study, membrane dysfunction was stronger in plants stressed in autumn than in winter, when plant tissues were in deep dormancy. In autumn, after freezing desiccation at $-10^{\circ} \mathrm{C}$, a maximum intensity of changes was observed when the water content of needles decreased to $20 \%$ (Fig. 1b). The increased ROS production led to membrane deterioration. It resulted in lipid peroxidation (increased MDA level), (Fig. 3a), decreased phosphatidylcholine (PC) level, and increased concentration of phosphatidic acid (PA) (Table 1). The increased PA content suggests that during freeze-induced desiccation stress in spruce needles, phospholipase D cleaves membrane phospholipids to produce PA and free head groups (Pukacka 1993; Sang et al. 2001). In vivo the PA induced ROS production in Arabidopsis leaves (Park et al. 2004). Next, the PA has a tendency to form hexagonal II phase in presence of $\mathrm{Ca}^{2+}$, which may lead to membrane destabilization (Park et al. 2004). During stress conditions, both phospholipase D and PA formation are important steps in signal transduction and in the cascades of reactions involved in the regulation of protein kinases, in the release of intercellular calcium (Heino and Palva 2003; Kacperska 2004). It was observed that phospholipase D stimulated the activity NADPH-dependent oxidases, with the consequent formation of $\mathrm{O}_{2}{ }^{\circ-}$, which is a precursor of $\mathrm{H}_{2} \mathrm{O}_{2}$ (Sang et al. 2001).

This resulted in biophysical changes within membranes, which caused intensive ion leakage (Table 1). Earlier studies showed that a rapid increase in ion leakage from Norway spruce tissues is closely associated with damage to components of cell membranes (Pukacki and Pukacka 1987). A similar rise in ion leakage from root tissues of Picea glauca seedlings has been observed under the influence of their storage at $-6^{\circ} \mathrm{C}$ (Wang and Zwiazek 1999).

In this study, the freezing resistance of the spruce needles in winter at $-3^{\circ} \mathrm{C}\left(\mathrm{LT}_{50}\right)$, assessed on the basis of ion leakage, decreased from $-32^{\circ} \mathrm{C}$ to $-25^{\circ} \mathrm{C}$ after freezing desiccation for 30 days in $\mathrm{ES}$ plants, but at $-10^{\circ} \mathrm{C}$ their cold resistance decreased to $-11^{\circ} \mathrm{C}$ (Fig. 1a). As a consequence, water diffuses more strongly at $-10^{\circ} \mathrm{C}$ than at $-3^{\circ} \mathrm{C}$, from the needle cells through the plasma membrane to the ice crystals in the extracellular spaces. The water potential (MPa) of extracellular ice is related to the low temperatures, $\Psi_{\mathrm{T}}$ (ice) $=-1.16\left({ }^{\circ} \mathrm{C}\right)$, (Guy 1990). Thus the water potential of the ice at $-10^{\circ} \mathrm{C}$ would be $-11.6 \mathrm{MPa}$, which indicates a drastic water stress, much greater than the water deficits that occur in spruce seedlings (-2.4 MPa) during drought stress (Kamińska-Rożek and Pukacki 2004).

The glutathione content of needles of coniferous trees ranges from 300 to $700 \mathrm{nM} \mathrm{g}^{-1} \mathrm{FW}$, but the oxidized form (GSSG) accounts for only 3-5\% (Anderson et al. 1992). Many studies reported increased GSH levels in winter (Doulis et al. 1993). A direct causal connection between cold tolerance and glutathione reductase activity was established by McKersie et al. (2000). Freezing desiccation caused a decline in GSH and AsA levels in needles, especially in the seedlings whose needles water content fell below $40 \%$. That is why those compounds are so important in freezing tolerance of plants. An important function in protection against peroxidation of membrane lipids during freezing desiccation of spruces should be performed by $\alpha$-tocopherol. Tocopherols inhibit oxidation induced by single oxygen in two ways: reacting with single oxygen by physical quenching or by chemical reactions (Kamal-Eldin and Appelqvist 1996). However, its level declined with the increasing stress of freezing desiccation (Fig. 3b). One of the reasons for this situation could be the progressive degradation of $\alpha$-tocopherol during non-enzymatic scavenging of free radicals in thylakoid membranes, as its synthesis was blocked at low temperatures.

The results of this study and published data indicate that the full efficiency of the antioxidative system in plant tissues is not possible without participation of important enzymes (SOD, POX, catalase). SOD transforms $\mathrm{O}_{2}{ }^{--}$into $\mathrm{H}_{2} \mathrm{O}_{2}$, which is removed with the use of catalase and POX. The decrease in POX activity during freezing stress was probably associated with the sensitivity of this enzyme to desiccation process (Fig. 5b). Peroxidases play a key role in the ascorbate-glutathione cycle of reduction of $\mathrm{H}_{2} \mathrm{O}_{2}$ to $\mathrm{H}_{2} \mathrm{O}$ (Foyer et al. 1994). Results of this study suggest that 
under the influence of freezing desiccation in spruce needles, the increase in SOD activity depended to a large extent on the cold acclimation stage of spruce tissues (Fig. 5a). Moreover, SOD activity in needles increased as late as after 30 days at an early stage of cold acclimation (in autumn) and the increase was the more intensive, the stronger was the oxidative stress induced by ROS production.

In summary, the results of the present study show that long-term storage of spruce seedlings in freezing temperatures resulted in desiccation and oxidative stress, which led to membrane degradation, decreased levels of low molecular antioxidants: GSH, AsA and $\alpha$-tocopherol, increased SOD activity and decreased POX activity. In addition, the results demonstrate that intensity and duration of freezing desiccation of cells and the cold acclimation stage of spruce exert a stronger influence on seedlings than does low storage temperature itself. The fully acclimated spruce seedlings in winter (January), submitted to freezing desiccation, tolerate desiccation stress better than less cold-hardened plants in autumn (October). We also conclude that the relationship between the antioxidative mechanisms and molecular cold acclimation processes could increase plant tolerance to freezing desiccation.

\section{ACKNOWLEDGEMENTS}

We wish to thank Mgr Ing Stanisław Zaradny from the Krotoszyn Forest District for providing spruce seedlings and Mariola Matelska for technical assistance. This work was financially supported by the State Committee for Scientific Research (KBN).

\section{LITERATURE CITED}

ARORA R., ROWLAND L., TANINO K. 2003. Induction and release of bud dormancy in woody perennials: A science comes of age. HortScience 38: 911-921.

AMES D.N. 1966. Assay of inorganic phosphate, total phosphate and phosphatases. In: Methods in Enzymology. S.P. Colowick, N.O. Kaplan (eds), Academic Press, New York, pp. 115-118.

ANDERSON J.V., CHEVONE B.I., HESS J.L. 1992. Seasonal variation in the antioxidant system of eastern white pine needles. Plant Physiol. 98: 501-508.

BRADFORD M.M. 1976. A rapid and sensitive method for the quantitation of microgram of quantities of protein utilizing the principle of protein-dye binding. Anal. Biochem. 72: 248-254.

CHANCE B., MAEHLY A.C. 1955. Assay of catalases and peroxidases. In: Methods in Enzymology. S.P. Colowick, N.O. Kaplan (eds), Academic Press, New York, pp 764-775.

DOKE N. 1983. Generation of superoxide anion by potato tuber protoplasts during the hypersensitive response to hyphal wall components of Phytophthora infestans and specific inhibition of the reaction by suppressors of hypersensitivity. Physiol. Plant Pathol. 23: 359-367.

DOULIS A.G., HAUSLADEN A., MONDY B., ALSCHER R.G., CHEVONE B.I., HESS J.L., WEISER R.L. 1993. Antioxidant response and winter hardiness in red spruce (Picea rubens Sarg.). New Phytol. 123: 365-374.

FOYER C.H., LELANDAIS M., KUNERT K.J. 1994. Photooxidative stress in plants. Physiol. Plant. 92: 696-717.

FOYER C.H., NOCTOR G. 2000. Oxygen processing in photosynthesis: regulation and signalling. New Phytol. 146: 359-388.

GIANNOPOLITIS C.N., RIES S.K. 1977. Superoxide dismutase. I. Occurrence in higher plants. Plant Physiol. 59: 309-314.
GUY C.L. 1990. Cold acclimation and freezing stress tolerance: role of protein metabolism. In: Annual Rev. Plant Physiol. and Plant Mol. Biol. 41: 187-223.

HEATH R.L., PACKER L. 1968. Photoperoxidation in isolated chloroplasts. I. Kinetics and stoichiometry of fatty acid peroxidation. Arch. Biochem. Biophys. 125: 189-198.

HEINO P., PALVA E.T. 2003. Signal transduction in cold acclimation. In: Plant Responses to Abiotic Stress. H. Hirt, K. Shinozaki (eds), Springer-Verlang Berlin Heidelberg, pp. 151$-186$.

KACPERSKA A. 1999. Plant responses to low temperature: signaling pathways involved in plant acclimation. In: Cold-Adapted Organisms. Ecology, Physiology and Molecular Biology. R. Margesin and F. Schinner (eds) Springer-Verlang Berlin Heidelberg. pp. 79-103.

KACPERSKA A. 2004. Sensor types in signal transduction pathways in plant cells responding to Abiotic stressors: do they depend on stress intensity? Physiol. Plantarum 122: 159-168.

KAMAL-ELDIN A., APPELQVIST L.A. 1996. The chemistry and antioxidant properties of tocopherols and tocotrienols. Lipids 31: 671-701.

KAMIŃSKA-ROŻEK E., PUKACKI P.M. 2004. Effect of water deficit on oxidative stress and degradation of cell membranes in needles of Norway spruce (Picea abies). Acta Physiol. Plant. 26: 431-442.

KENDALL E.J., MCKERSIE B.D. 1989. Free radical and freezing injury to cell membranes of winter wheat. Physiol. Plant. 76: 86-94.

LAW M.Y., CHARLES S.A., HALLIWELL B. 1983. Glutathione and ascorbic acid in spinach (Spinacia oleracea) chloroplasts. The effect of hydrogen peroxide and of paraquat. Biochem. J. 210: 899-903.

MCKERSIE B.D., MURNAGHAN J., JONES K.S., BOWLEY S.R. 2000. Iron-superoxidase dismutase expression in transgenic Alfalfa increases winter survival without a detectable increase in photosynthetic oxidative stress tolerance. Plant Physiol. 122: 1427-1437.

NICHOLS B.W., HARRIS R.V., JAMES A.T. 1965. The lipid metabolism of the blue-green algae. Biochem. Biophys. Res. Commun. 20: 256-262.

PASTORI G.M., FOYER C.H. 2002. Common components, networks, and pathways of cross-tolerance to stress. The central role of "redox" and abscisic acid-mediated controls. Plant Physiol. 129: 460-468.

POLLE A., KRONIGER W., RENNENBERG H. 1996. Seasonal fluctuations of ascorbate-related enzymes: acute and delayed effects of late frost in spring on antioxidative systems in needles of Norway spruce (Picea abies L.). Plant Cell Physiol. 37: 717-725.

PUKACKA S. 1993. Phospholipase D activity during long-term storage of Acer platanoides seeds in the imbibed state and desiccation of Acer saccharinum seeds. Acta Physiol. Plant. 15: 147-153.

PUKACKA S., PUKACKI P.M. 2000. Seasonal changes in antioxidant level of Scots pine (Pinus sylvestris L.) needles exposed to industrial pollution. II. Enzymatic scavengers activities. Acta Physiol. Plant. 22: 457-464.

PUKACKI P.M. 2004. The effect of industrial air pollution on membrane lipid composition of Scots pine (Pinus sylvestris L.) needles. Acta Soc. Bot. Pol. 73: 187-191.

PUKACKI P.M., KENDALL E.J., MCKERSIE B.D. 1991. Membrane injury during freezing stress to winter wheat (Triticum aestivum L.) crowns. J. Plant Physiol. 138: 516-521.

PUKACKI P., PUKACKA S. 1987. Freezing stress and membrane injury of Norway spruce (Picea abies) tissues. Physiol. Plant. 69: 156-160.

SANG Y., CUI D., WANG X. 2001. Phospholipase D and pohosphatidic acid-mediated generation of superoxide in Arabidopsis. Plant Physiol. 126: 1449-1458. 
SEDLAK J., LINDSAY R.H. 1968. Estimation of total, proteinbound, and nonprotein sulfhydryl groups with Ellman's reagent. Anal. Biochem. 25: 192-205.

SIKORSKA E, KACPERSKA A. 1982. Modification of phospholipase D activity during frost hardening of winter rape plants. In: Biochemistry and Metabolism of Plant Lipids. J.F.G.M. Wintermans, P.C.J. Kuiper (eds), Elsevier, Biomedical Press, Amsterdam-New York-Oxford, pp. 415-418.

SUTINEN M.-L., ARORA R., WISNIEWSKI M., ASWORTH E., STRIMBECK R., PALTA J. 2001. Mechanisms of frost survival and freeze-damage in nature. In: Conifer Cold Hardiness. F.J. Bigras, S.J. Colombo (eds), Kluwer Academic Publ, Dordrecht, pp. 89-120.

THURMAN R.G., LEY H.G., SCHOLZ R. 1972. Hepatic microsomal ethanol oxidation: hydrogen peroxide formation and the role of catalase. Eur. J. Biochem. 25: 420-430.
WANG Y., ZWIAZEK J.J. 1999. Effects of storage temperature on physiological characteristics of fall-lifted white spruce (Picea glauca) bareroot seedlings. Can. J. For. Res. 29: 679$-686$.

YOSHIDA S. 1979. Freezing injury and phospholipid degradation in vivo in woody plant cells. II. Regulatory effects of divalent cations on activity of membrane-bound phospholipase D. Plant Physiol. 64: 247-251.

ZWIAZEK J.J., RENAULT S., CROSER C., HANSEN J., BECK E. 2001. Biochemical and physiological changes in relation to cold hardiness. In: Conifer Cold Hardiness. F.J. Bigras, S.J. Colombo (eds), Kluwer Academic Publ, Dordrecht, pp. 165-186 . 